\title{
FAKTOR-FAKTOR YANG MEMPENGARUHI KEBERHASILAN PROGRAM UPAYA KHUSUS PADI DI KABUPATEN TABANAN
}

\section{Factors That Influence The Success of The Rice Special Effort Program in Tabanan Regency}

\author{
I Gede Made Artha Sudewa Wijaya, I Dewa Putu Oka Suardi, Nyoman Suparta
}

Program Studi Magister Agribisnis, Program Pascasarjana, Universitas Udayana, Bali, Indonesia

Email: sudewa.wijaya@gmail.com

\begin{abstract}
Tabanan regency is one of the beneficiaries of Upsus program. The purpose of this study is (1) to analyze the influence of extension workers competence and the nature of innovation on farmer behavior, (2) to analyze the influence of extension workers competence and the nature of innovation on the success of Upsus program, and (3) to analyze the influence of farmer behavior on the success of Upsus program. This research was conducted in Tabanan Regency. Data collection was conducted from February to May 2018. The population in this study were all farmers who have followed the Upsus program in 2017. The samples used were 96 farmers determined using Slovin formula with $10 \%$ confidence level. Samples were taken using propotional purposive sampling technique. Data analysis used descriptive and statistical method with SmartPLS 3.0 version. The result of the research shows that: (1) the competency of extension workers significantly affect on the farmers behaviour, the nature of innovation did not significantly affect on the farmers behaviour; (2) the competency of extension workers significantly affect on the success of the Upsus program, the nature of innovation did not significantly affect on the success of the Upsus program; (3) the farmers behavior significantly affect on the success of the Upsus program. Suggestions that can be given are: (1) The competence of extension agents in Tabanan Regency in mastering the material to identify new problems needs to be improved; (2) assessment of the suitability of the tractor engine specification innovation needs to be improved; (3) non-formal education through training and technical guidance to farmers needs to be improved; (4) government support for irrigation infrastructure through rehabilitation of tertiary irrigation networks and the construction of trench dams need to be improved; (5) the development of other research needs to be carried out with additional constructs of farmer characteristics and studies in the economic field.
\end{abstract}

Keyword: Competence, Innovation, Behavior, Upsus Program

\begin{abstract}
ABSTRAK
Kabupaten Tabanan merupakan salah satu penerima bantuan program Upsus. Penelitian ini bertujuan untuk: (1) menganalisis pengaruh kompetensi penyuluh dan sifat inovasi terhadap perilaku petani, (2) menganalisis pengaruh kompetensi penyuluh dan sifat inovasi terhadap keberhasilan program Upsus, dan (3) menganalisis pengaruh perilaku petani terhadap keberhasilan program Upsus. Penelitian ini dilakukan di Kabupaten Tabanan. Pengumpulan data dilakukan dari bulan Februari sampai Mei 2018. Populasi dalam penelitian ini adalah petani yang mengikuti program Upsus tahun 2017 di Kabupaten Tabanan. Jumlah sampel yang digunakan sebanyak 96 petani yang ditentukan menggunakan rumus Slovin dengan tingkat kepercayaan sebesar 10\%. Sampel diambil menggunakan teknik propotional purposive sampling. Data di analisis menggunakan metode analisis deskriptif dan statistik menggunakan SmartPLS versi 3.0. Hasil penelitian menunjukkan: (1) kompetensi penyuluh berpengaruh nyata terhadap perilaku petani, sifat inovasi berpengaruh tidak nyata terhadap perilaku petani; (2) kompetensi penyuluh berpengaruh nyata terhadap keberhasilan program Upsus, sifat inovasi berpengaruh tidak nyata terhadap keberhasilan program Upsus; (3) perilaku petani berpengaruh nyata terhadap keberhasilan program Upsus. Saran yang dapat diberikan dalam penelitian ini yaitu: (1) kompetensi penyuluh di Kabupaten Tabanan dalam menguasai materi untuk mengidentifikasi masalah-masalah baru perlu ditingkatkan; (2) pengkajian terhadap kesesuaian inovasi spesifikasi mesin traktor perlu ditingkatkan; (3) pendidikan non formal melalui pelatihan maupun bimbingan teknis kepada petani perlu ditingkatkan; (4) dukungan pemerintah terhadap infrastruktur irigasi melalui rehabilitasi jaringan irigasi tersier maupun pembuatan dam parit perlu di tingkatkan; (5) pengembangan penelitian lain perlu dilakukan dengan tambahan konstruk karakteristik petani dan kajian bidang ekonomi.
\end{abstract}

Kata kunci: Kompetensi, Inovasi, Perilaku, Program Upsus 


\section{PENDAHULUAN}

\section{Latar Belakang}

Sektor pertanian merupakan salah satu sektor andalan dalam pembangunan ekonomi nasional karena memiliki kontribusi yang dominan, baik secara langsung maupun secara tidak langsung dalam pencapaian tujuan pembangunan perekonomian nasional. Dalam rangka mencapai misi pembangunan nasional sektor pertanian, Kementerian Pertanian Republik Indonesia terus berupaya menerapkan berbagai inovasi melalui berbagai program untuk mengembangkan sektor pertanian.

Kabupaten Tabanan merupakan salah satu penerima bantuan program Upsus melalui budidaya padi jenis inbrida tahun 2017 berdasarkan SK Dinas Kabupaten Tabanan nomor: 029/DISTAN/2017 (Dinas, Pertanian, 2017). Program Upsus sudah terlaksana di Kabupaten Tabanan dari Tahun 2015. Walaupun pemerintah berupaya mendukung sektor pertanian, tetap saja kebijakan impor beras masih dilakukan.

Pada tahun 2011 pemerintah mengimpor beras sebesar 2,75 juta ton, dan jumlah ini merupakan jumlah impor terbesar dari kurun waktu tahun 20002015 (BPS, 2016). Secara nasional produksi padi tahun 2015 meningkat dari tahun sebelumnya dari 71,28 juta ton menjadi 75,398 juta ton, sedangkan jumlah produksi dan luas panen di Provinsi Bali pada tahun 2015 menurun dari tahun sebelumnya dari 857.944 ton menjadi 853.710 ton, akan tetapi jumlah produktivitasnya meningkat sebesar 2,02 kuintal/hektar (BPS, 2016). Penurunan hasil produksi di Bali yang relatif tinggi terjadi di Kabupaten Tabanan sebesar 20.082 ton atau 9,38 persen dan penurunan luas panen yang relatif tinggi juga terjadi di Kabupaten Tabanan sebesar 4.518 hektar atau 12,25 persen (BPS, 2016). Oleh karena itu, perlu adanya pengkajian secara mendalam mengenai faktor-faktor yang mempengaruhi keberhasilan program Upaya Khusus padi di Kabupaten Tabanan.

\section{Rumusan Masalah}

Rumusan masalah penelitian ini adalah

1. Bagaimanakah pengaruh kompetensi penyuluh dan sifat inovasi terhadap perilaku petani dalam program Upsus di Kabupaten Tabanan?

2. Bagaimanakah pengaruh kompetensi penyuluh dan sifat inovasi terhadap keberhasilan program Upsus di Kabupaten Tabanan?

3. Bagaimanakah pengaruh perilaku petani terhadap keberhasilan program Upsus di Kabupaten Tabanan?

\section{Tujuan Penelitian}

Tujuan penelitian ini adalah

1. Menganalisis pengaruh kompetensi penyuluh dan sifat inovasi terhadap perilaku petani di Kabupaten Tabanan.
2. Menganalisis pengaruh kompetensi penyuluh dan sifat inovasi terhadap keberhasilan program Upsus di Kabupaten Tabanan.

3. Menganalisis pengaruh perilaku petani terhadap keberhasilan program Upsus di Kabupaten Tabanan.

\section{KAJIAN PUSTAKA}

\section{Program Upsus}

Peraturan Kementerian Pertanian Republik Indonesia Nomor: 03/Permentan/0T.140/2/2015 tentang pedoman Upaya Khusus (Upsus) peningkatan produksi padi, jagung, dan kedelai melalui program perbaikan jaringan irigasi dan sarana pendukungnya tahun anggaran 2015 telah menetapkan upaya khusus capaian swasembada berkelanjutan padi, jagung, dan kedelai (Kementan, 2015). Strategi capaian produksi padi meliputi: peningkatan produktivitas, perluasan areal tanam, dan peningkatan indeks pertanaman (Kementan, 2017).

\section{Teori Kompetensi Penyuluh Pertanian}

Kompetensi adalah suatu karakteristik dasar individu yang memiliki suatu hubungan yang kausal atau hubungan sebab akibat dengan kriteria yang dijadikan acuan atau standar, efektif, atau berpenampilan superior di tempat kerja pada situasi tertentu (Nursalam dan Efendi, 2008). Kompetensi didefinisikan sebagai kumpulan pengetahuan, keterampilan, dan sikap yang berhubungan satu sama lain yang berpengaruh pada sebagian besar pekerjaan seseorang (peranan atau tanggung jawab), yang berkolerasi dengan kinerja dan dapat diukur dan diterima sebagai suatu standar kinerja yang baik; dan pengetahuan, keterampilan dan sikap itu dapat diperbaiki melalui pelatihan dan pengembangan (Marius, 2007).

\section{Teori Inovasi}

Soekartawi (1988) mengemukakan bahwa inovasi adalah suatu ide yang dipandang baru oleh sesorang. Sebuah inovasi biasanya terdiri dari dua komponen yaitu komponen ide dan komponen obyek yang berupa aspek material atau produk fisik dari ide tersebut (Rogers, 2003).

\section{Teori Perilaku}

Perilaku adalah cara bertindak yang menunjukkan tingkah laku seseorang dan merupakan hasil kombinasi antara pengembangan anatomis, fisiologis dan psikologis, dan pola prilaku dikatakan sebagai tingkah laku yang dipakai seseorang dalam melaksanakan kegiatannya (Kast dan Rosenzweig, 1995). Memahami perilaku dapat dilihat dari pendekatan kognitif, meliputi kegiatan sadar seperti berpikir, mengetahui, memahami dan kesemuanya itu merupakan faktor yang menentukan perilaku (Kast dan Rosenzweig, 1995). 


\section{KERANGKA KONSEP DAN HIPOTESIS}

\section{Kerangka Konsep Penelitian}

Petani padi di Kabupaten Tabanan merupakan salah satu penerima bantuan program Upsus padi. Pada penelitian ini dibagi menjadi dua konstruk yaitu konstruk eksogen dan endogen. Konstruk eksogen terdiri atas kompetensi penyuluh, sifat inovasi, dan perilaku petani, sedangkan konstruk endogen yaitu keberhasilan program Upsus. Konstruk kompetensi penyuluh diharapkan mampu mempengaruhi perilaku petani dan menunjang keberhasilan program Upsus. Konstruk sifat inovasi diharapkan mampu mempengaruhi perilaku petani dan menunjang keberhasilan program Upsus. Konstruk perilaku petani diharapkan mampu mempengaruhi keberhasilan program Upsus. Analisis deskriptif kuntitatif dan kualitatif digunakan untuk memberikan penjabaran terhadap program ini sehingga adanya kesimpulan dan rekomendasi yang diberikan kepada petani padi di Kabupaten Tabanan.

\section{Hipotesis Penelitian}

Hipotesis yang akan diuji dalam penelitian ini berdasarkan literatur yang tertuang dalam bab tinjauan pustaka, kerangka berpikir, dan konsep penelitian adalah sebagai berikut.

1. Kompetensi penyuluh dan sifat inovasi berpengaruh positif terhadap perilaku petani padi dalam program Upsus di Kabupaten Tabanan.

2. Kompetensi penyuluh dan sifat inovasi berpengaruh positif terhadap keberhasilan program Upsus padi di Kabupaten Tabanan.

3. Perilaku petani berpengaruh positif terhadap keberhasilan program Upsus padi di Kabupaten Tabanan.

\section{METODELOGI PENELITIAN}

\section{Lokasi dan Waktu Penelitian}

Penelitian ini dilaksanakan di Kabupaten Tabanan. Petani yang diteliti adalah petani padi yang mengetahui dan atau berpartisipasi dalam program Upsus. Waktu penelitian dilakukan dari Februari hingga Mei 2018.

\section{Jenis dan Sumber Data}

Jenis data yang digunakan dalam penelitian ini meliputi data kuantitatif dan kualitatif. Data kuantitatif meliputi: (1) data kompetensi penyuluh, sifat inovasi, perilaku petani, dan keberhasilan program Upsus; (2) data karakteristik petani yang terdiri atas umur, luas garapan, lama pendidikan formal, lama pengalaman berusahatani, dan jumlah tanggungan keluarga. Data kualitatif meliputi profil dan struktur organisasi di lokasi penelitian.

Data yang digunakan dalam penelitian ini meliputi data primer yang meliputi: (1) data karakteristik petani; (2) data kompetensi penyuluh, sifat inovasi, dan keberhasilan program Upsus. Data sekunder meliputi: (1) data produksi dan luas panen padi di Indonesia dan Provinsi Bali tahun 2011-2015 serta data impor beras dari tahun 2000-2015 yang dikeluarkan oleh Badan Pusat Statistik; (2) data profil dan struktur organisasi di lokasi penelitian; (3) data penerima bantuan program Upsus tahun 2017.

\section{Populasi dan Sampel}

Populasi penelitian ini yaitu petani yang berpartisipasi dalam program Upsus yang terdiri atas: (1) Subak Meliling di Kecamatan Kerambitan sebanyak 988 petani, (2) Subak Bungan Kapal di Kecamatan Tabanan sebanyak 140 petani, (3) Subak Nyitdah III di Kecamatan Kediri sebanyak 607 petani, (4) Subak Semaja di Kecamatan Selemadeg Barat sebanyak 98 petani, dan (5) Subak Rejasa di Kecamatan Penebel sebanyak 306 petani. Teknik sampling dalam penelitian ini menggunakan metode propotional purposive sampling. Jumlah sampel penelitian ini sebanyak 96 petani yang ditentukan dengan menerapkan rumus Slovin dengan tingkat kepercayaan $10 \%$. Pengambilan sampel dilakukan secara proporsi dan ditentukan secara purposive. Sampel penelitian ini dapat dilihat pada Tabel 1. berikut ini.

Tabel 1. Sampel Penelitian

\begin{tabular}{clc} 
No & Nama Subak & $\begin{array}{c}\text { Jumlah Sampel } \\
\text { (Petani) }\end{array}$ \\
\hline 1 & Subak Meliling & 44 \\
2 & Subak Bungan Kapal & 7 \\
3 & Subak Nyitdah III & 27 \\
4 & Subak Semaja & 4 \\
5 & Subak Rejasa & 14 \\
\hline & Total & $\mathbf{9 6}$
\end{tabular}

Sumber: Data sekunder (diolah), 2018.

\section{Metode Pengumpulan Data}

Pengumpulan data dalam penelitian ini dilakukan dengan menerapkan metode (1) Pengamatan (observation) pada lokasi sampel penelitian. (2) Wawancara (interview) dengan menggunakan pedoman kuisioner terhadap sampel petani yang berpartisipasi dalam program Upsus di Kabupaten Tabanan tahun 2017. (3) Dokumentasi selama berlangsungnya proses penelitian.

\section{Metode Analisis Data}

Metode analisis data yang digunakan dalam penelitian ini dilakukan dengan analisis deksriptif dan analisis statistik. Analisis deksriptif dilakukan dengan melihat nilai capaian skor masing-masing konstruk, indikator, maupun parameter yang dibagi menjadi lima kategori. Analisis statistik dilakukan dengan 
analisis SEM (Structural Equation Modeling) yang meliputi evaluasi model pengukuran (outer model) dan evaluasi model struktural (inner model) dengan aplikasi SmartPLS versi 3.0.

Sugiyono (2010) mengemukakan bahwa analisis deskriptif dilakukan untuk mengetahui nilai variabel mandiri, baik satu variabel, atau lebih (independen) tanpa membuat perbandingan, atau menghubungkan dengan variabel yang lain. Penentuan kategori konstruk dilakukan berdasarkan skor yang dicapai responden dengan menggunakan rumus interval class sebagai berikut.

$$
\begin{aligned}
\mathrm{i}= & \text { Jarak } / \text { Jumlah kelas } \\
\mathrm{i}= & \text { interval class. } \\
\text { Jarak }= & \text { nilai skor tertinggi dikurangi } \\
& \text { nilai skor terendah. } \\
\text { Jumlah Kelas }= & \text { jumlah kelas atau kategori } \\
& \text { yang ditentukan. }
\end{aligned}
$$

Jumlah kategori pada penelitian ini adalah lima, sehingga interval class $=(5-1) / 5=0,8$. Konstruk diklasifikasikan menjadi lima kategori yang terdiri atas: (1) nilai capaian skor > 4,2 sampai dengan lima menunjukkan kompetensi penyuluh termasuk kategori sangat kompeten, sifat inovasi dan perilaku petani termasuk kategori sangat baik, dan keberhasilan program Upsus termasuk kategori sangat berhasil; (2) nilai capaian skor > 3,4 sampai dengan 4,2 menunjukkan kompetensi penyuluh termasuk kategori kompeten, sifat inovasi dan perilaku petani termasuk kategori baik, dan keberhasilan program Upsus termasuk kategori berhasil; (3) nilai capaian skor > 2,6 sampai dengan 3,4 menunjukkan kompetensi penyuluh termasuk kategori cukup kompeten, sifat inovasi dan perilaku petani termasuk kategori cukup baik, dan keberhasilan program Upsus termasuk kategori cukup berhasil; (4) nilai capaian skor > 1,8 sampai dengan 2,6 menunjukkan kompetensi penyuluh termasuk kategori tidak kompeten, sifat inovasi dan perilaku petani termasuk kategori tidak baik, dan keberhasilan program Upsus termasuk kategori tidak berhasil; (5) nilai capaian skor satu sampai dengan 1,8 menunjukkan kompetensi penyuluh termasuk kategori sangat tidak kompeten, sifat inovasi dan perilaku petani termasuk kategori sangat tidak baik, dan keberhasilan program Upsus termasuk kategori sangat tidak berhasil.

Evaluasi model pengukuran (outer model) dilakukan dengan uji validitas dan uji reliabilitas. Ghozali (2011) menyebutkan kriteria evaluasi model pengukuran (outer model) sebagai berikut: (1) Nilai loading factor $>0,70$ untuk uji validitas convergent. (2) Nilai AVE (Average Variance Extracted) $>0,50$ untuk uji validitas discriminant. (3) Nilai composite reliability > 0,70 untuk confirmatory research. (4) Nilai cronbach's alpha $>0,70$ untuk confirmatory research. Evaluasi model struktural dilakukan dengan melihat nilai $R$-square dan $\mathrm{Q}^{2}$ predictive. Ghozali (2011) menyebutkan kriteria penilaian evaluasi model struktural (inner model) sebagai berikut: (1) Nilai $R$-square 0,$67 ; 0,33$; dan 0,19 menunjukkan model kuat, moderat, dan lemah. (2) Nilai $Q^{2}$ predictive $>0$ menunjukkan model mempunyai predictive relevance, sedangkan $<0$ menunjukkan model kurang memiliki predictive relevance. Pengujian hipotesis dilakukan dengan uji statistik $\mathrm{t}(t$ test). Kriteria penentuan uji statistik $\mathrm{t}(t$-test) yaitu:

1. Jika nilai $\mathrm{P}-$ Value $<0,05$ ( $\mathrm{t}_{\text {hitung }}>\mathrm{t}_{\text {tabel }} 5 \%$ ) maka konstruk dikatakan berpengaruh nyata.

2. Jika nilai P-Value $>0,05\left(\mathrm{t}_{\text {hitung }}<\mathrm{t}_{\text {tabel }} 5 \%\right)$ maka konstruk dikatakan berpengaruh tidak nyata.

\section{HASIL DAN PEMBAHASAN}

\section{Karakteristik Petani}

Petani padi di Kabupaten Tabanan memiliki rata-rata luas garapan sebesar 0,35 hektar dengan kisaran luasan dari 0,05 sampai dengan 1,12 hektar. Hernanto (1996) menyebutkan bahwa luas garapan < 0,05 termasuk kategori luas garapan yang sempit. Hal ini mengindikasikan bahwa petani akan kesulitan mengembangkan skala usahataninya karena rata-rata petani berusahatani di lahan yang sempit.

Petani padi di Kabupaten Tabanan yang berpartisipasi dalam program Upsus memiliki rata-rata umur selama 65 tahun dengan kisaran umur dari 35 sampai dengan 75 tahun. Nurhasikin (2013. dalam Wijaya, 2016) menyatakan usia > 64 tahun termasuk kategori usia tidak produktif. Hal ini mengindikasikan bahwa petani di Kabupaten Tabanan cenderung belum mampu bekerja secara optimal karena mudah lelah.

Petani padi di Kabupaten Tabanan yang berpartisipasi dalam program Upsus memiliki rata-rata lama pendidikan formal selama delapan tahun dengan kisaran selama empat sampai dengan 16 tahun. Soekartawi (2006) menyatakan bahwa petani yang berpendidikan tinggi relatif lebih cepat dalam melaksanakan adopsi inovasi. Hal ini mengindikasikan bahwa apabila petani padi di Kabupaten Tabanan yang berpartisipasi dalam program Upsus hanya mengandalkan pendidikan formalnya, maka petani akan cenderung lambat mengadopsi inovasi.

Petani padi di Kabupaten Tabanan yang berpartisipasi dalam program Upsus memiliki rata-rata jumlah tanggungan keluarga sebanyak tiga orang dengan kisaran satu sampai dengan sembilan orang. Soekartawi (2006) mengungkapkan semakin banyak anggota keluarga akan semakin besar pula beban hidup yang akan ditanggung atau harus dipenuhi. Hal ini mengindikasikan bahwa semakin banyak jumlah anggota keluarga yang ditanggung tentu akan mempengaruhi keputusan petani, keberlanjutan, dan keberhasilan usahataninya.

Petani padi di Kabupaten Tabanan yang berpartisipasi dalam program Upsus memiliki rata-rata lama pengalaman usahatani selama 39 tahun dengan kisaran selama tiga sampai dengan 57 tahun. Maryani (2014) mengungkapkan bahwa kegiatan usahatani yang dilakukan oleh petani biasanya turun temurun, 
cara bercocok tanam yang dilakukan biasanya mengikuti kebiasaan yang dilakukan oleh keluarganya. Hal ini mengindikasikan bahwa walaupun petani di Kabupaten Tabanan yang berpartisipasi dalam program Upsus akan lebih mudah dalam menerapkan inovasi, tetapi petani yang sudah berpengalaman cenderung sulit menerima inovasi baru karena sulitnya merubah kebiasaan petani dalam berusahatani dan tingkat pendidikan formal petani yang masih rendah dari standar pendidikan nasional wajib belajar sembilan tahun.

Deskripsi Konstruk Kompetensi Penyuluh (KP), Sifat Inovasi (SI), Perilaku Petani (PP), dan Keberhasilan Program Upsus (KPU)

Analisis data secara diskriptif berfungsi untuk mendiskripsikan nilai capaian skor konstruk yang terdiri atas: kompetensi penyuluh, sifat inovasi, perilaku petani, dan keberhasilan program Upsus. Penafsiran terhadap hasil nilai capaian skor konstruk penelitian ini secara rinci dapat dilihat pada Tabel 2 . berikut ini.

Tabel 2. Nilai Capaian Skor Konstruk

\begin{tabular}{ccc}
\hline Konstruk & Nilai Capaian Skor & Kategori \\
\hline KP & 7.020 & Kompeten \\
SI & 1.993 & Baik \\
PP & 8.152 & Baik \\
KPU & 4.268 & Berhasil \\
\hline
\end{tabular}

Sumber: Data primer (diolah), 2018.

Nilai capaian skor kompetensi penyuluh (KP) sebesar 7.020 yang berarti sudah berkompeten dalam melakukan penyuluhan dan membina petani padi yang berpartisipasi dalam program Upsus. Kompetensi penyuluh (KP) yang meliputi keterampilan berkomunikasi (KB), penguasaan materi (PM), kemampuan memotivasi (KM), dan interaksi sosial (IS) termasuk kategori kompeten karena penyuluh di Kabupaten Tabanan memiliki pengalaman dalam melakukan penyuluhan dan adanya pengarahan dari Dinas Pertanian Kabupaten Tabanan sebelum pelaksanaan program Upsus.

Nilai capaian skor sifat inovasi (SI) sebesar 1.993 yang berarti sifat inovasi yang ditawarkan kepada petani di Kabupaten Tabanan dalam program Upsus sudah baik. Sifat inovasi (SI) yang terdiri atas keuntungan relatif (KR), kesesuaian inovasi (KI), tingkat kerumitan (TK), dapat dicoba (DD), mudah diamati (MD) termasuk kategori baik karena penyuluh berkompeten dalam menjelaskan secara detail petunjuk teknis dan pelaksanaan program Upsus. Hal ini berdampak kepada pemahaman petani bahwa visi dan misi program Upsus sejalan dengan harapan petani untuk meningkatkan produktivitas agar kesejahteraan petani menjadi meningkat.

Nilai capaian skor perilaku petani (PP) sebesar 8.152 yang berarti perilaku petani padi di Kabupaten
Tabanan yang berpartisipasi dalam program Upsus sudah baik. Perilaku petani (PP) yang terdiri atas pengetahuan $(\mathrm{P})$, sikap $(\mathrm{S})$, dan keterampilan $(\mathrm{K})$ termasuk dalam kategori baik karena memiliki pengalaman dalam berusahatani padi dan adanya kebijakan pengawalan dari penyuluh yang bertugas sebagai pendamping, aparat keamanan/militer yang bertugas sebagai pengawas, dan kalangan akademisi yang bertugas sebagai konsultan sehingga pembinaan kepada petani menjadi lebih optimal.

Nilai capaian skor keberhasilan program Upsus (KPU) sebesar 4.268 yang berarti pelaksanaan program Upsus di Kabupaten Tabanan sudah berhasil. Keberhasilan program Upsus (KPU) yang terdiri atas meningkatnya produktivitas (MP), perluasan areal tanam (PAT), dan peningkatan indeks pertanaman (PIP) termasuk kategori berhasil karena pemerintah daerah serius mendukung pelaksanaan program Upsus dengan mensinergikan program milik pemerintah daerah Kabupaten Tabanan, Provinsi Bali, dan pusat seperti program Gerbang Pangan Serasi, Simantri, bantuan dana operasional subak, dan UPPO (Unit Pengolahan Pupuk Organik). Sinergritas berbagai program milik pemerintah daerah maupun pusat membantu keberhasilan pelaksanaan program Upsus di Kabupaten Tabanan.

\section{Evaluasi Outer Model}

Kontribusi masing-masing indikator dalam membentuk konstruk dapat dilihat dari nilai outer loading. Secara rinci nilai outer loading seluruh indikator pembentuk konstruk dapat dilihat pada Tabel 3. berikut ini.

Tabel 3. Hasil Uji Outer Model

\begin{tabular}{ccc}
\hline Konstruk & Indikator & Outer Loading \\
\hline \multirow{3}{*}{ KP } & KB & 0,915 \\
& PM & 0,873 \\
& KM & 0,829 \\
& IS & 0,809 \\
\hline \multirow{2}{*}{ SI } & KR & 0,904 \\
& KI & 0,848 \\
& TK & 0,727 \\
& DD & 0,727 \\
& MD & 0,886 \\
\hline \multirow{2}{*}{ PP } & P & 0,719 \\
& S & 0,923 \\
& K & 0,941 \\
\hline \multirow{2}{*}{ KPU } & MP & 0,892 \\
& PAT & 0,837 \\
& PIP & 0,897 \\
\hline
\end{tabular}

Sumber: Data primer (diolah), 2018. 
Hasil pengujian outer model pada Tabel 3. menunjukkan bahwa masing-masing indikator memiliki nilai outer loading >0,70. Hal ini menunjukkan bahwa: (1) Indikator keterampilan berkomunikasi (KB), penguasaan materi (PM), kemampuan memotivasi (KM), dan interaksi sosial (IS) sudah valid dalam membentuk konstruk kompetensi penyuluh (KP); (2) Indikator keuntungan relatif (KR), kesesuaian inovasi (KI), tingkat kerumitan (TK), dapat dicoba (DD), dan mudah diamati (MD) sudah valid dalam membentuk konstruk sifat inovasi (SI); (3) Indikator pengetahuan (P), sikap (S), dan keterampilan (K) sudah valid dalam membentuk konstruk perilaku petani (PP); (4) Indikator meningkatnya produktivitas (MP), perluasan areal tanam (PAT), dan peningkatan indeks pertanaman (PIP) sudah valid dalam membentuk konstruk keberhasilan program Upsus (KPU).

Ghozali (2011) mengungkapkan kriteria uji discriminant validity yaitu nilai AVE $>0,50$ dan nilai $\sqrt{ }$ AVE $>$ AVE. Secara rinci hasil uji discriminant validity dari seluruh konstruk dapat dilihat pada Tabel 4. berikut ini.

Tabel 4. Hasil Uji Discriminant Validity

\begin{tabular}{ccc}
\hline Konstruk & Nilai AVE & Nilai $\sqrt{ }$ AVE \\
\hline KP & 0,736 & 0,858 \\
SI & 0,675 & 0,822 \\
PP & 0,752 & 0,867 \\
KPU & 0,766 & 0,875 \\
\hline
\end{tabular}

Sumber: Data primer (diolah), 2018.

Hasil pengujian discriminant validity pada Tabel 4 . menunjukkan bahwa konstruk kompetensi penyuluh $(\mathrm{KP})$, sifat inovasi (SI), perilaku petani (PP), dan keberhasilan program Upsus (KPU) sudah valid untuk memprediksi ukuran dari setiap indikatornya.

Uji reliabilitas konstruk diukur dengan dua kriteria yaitu composite reliability dan cronbach's alpha dari blok indikator yang mengukur konstruk dengan kriteria nilai composite reliability maupun cronbach's alpha $>0,70$. Secara rinci hasil pengujian composite reliability dan cronbach's alpha seluruh konstruk dapat dilihat pada Tabel 5. berikut ini.

Tabel 5. Hasil Uji Composite Reliability dan Cronbach's Alpha

\begin{tabular}{ccc}
\hline Konstruk & Composite Reliability & $\begin{array}{c}\text { Cronbach's } \\
\text { Alpha }\end{array}$ \\
\hline KP & 0,917 & 0,879 \\
SI & 0,912 & 0,877 \\
PP & 0,900 & 0,834 \\
KPU & 0,908 & 0,847 \\
\hline
\end{tabular}

Sumber: Data primer (diolah), 2018.

Hasil pengujian composite reliability dan cronbach's alpha pada Tabel 5. menunjukkan bahwa konstruk kompetensi penyuluh (KP), sifat inovasi (SI), perilaku petani (PP), dan keberhasilan program Upsus (KPU) sudah memiliki nilai composite reliability dan cronbach's alpha di atas 0,70 . Hal ini menunjukkan bahwa seluruh indikator sudah reliabel atau handal untuk mengukur konstruk.

\section{Evaluasi inner model}

Ghozali (2011) menyebutkan kriteria penilaian evaluasi model struktural (inner model) sebagai berikut: (1) Nilai $R$-square 0,$67 ; 0,33$; dan 0,19 menunjukkan model kuat, moderat, dan lemah. (2) Nilai $Q^{2}$ predictive $>0$ menunjukkan model mempunyai predictive relevance, sedangkan $<0$ menunjukkan model kurang memiliki predictive relevance. Secara rinci hasil uji goodness of fit model dan predictive relevance dapat dilihat pada Tabel 6 . berikut ini.

Tabel 6. Hasil Uji Goodness Of Fit Model dan Predictive Relevance

\begin{tabular}{ccc}
\hline Konstruk & $\boldsymbol{R}$-square & $\boldsymbol{Q}$-square \\
\hline PP & 0,949 & 0 \\
KPU & 0,919 & \\
\hline
\end{tabular}

Sumber: Data primer (diolah), 2018.

Keterangan:

$Q$-square $=1-\left(1-R_{P P}^{2}\right) \times\left(1-R^{2}{ }_{\text {PPU }}\right)$

$Q$-square $=1-(1-0,949) \times(1-0,919)$

$Q$-square $=0,996$

Hasil pengujian goodness of fit model pada Tabel 6 . menunjukkan bahwa: (1) model konstruk perilaku petani (PP) secara kuat diprediksi oleh konstruk kompetensi penyuluh (KP) dan sifat inovasi (SI); (2) model konstruk keberhasilan program Upsus (KPU) secara kuat diprediksi oleh kompetensi penyuluh (KP), sifat inovasi (SI), dan perilaku petani (PP); (3) model dan estimasi parameternya memiliki nilai observasi yang baik.

\section{Evaluasi koefisien struktural}

Evaluasi koefisien struktural bertujuan untuk menganalisis pengaruh kompetensi penyuluh dan sifat inovasi terhadap perilaku petani, pengaruh kompetensi penyuluh dan sifat inovasi terhadap keberhasilan program Upsus, dan pengaruh perilaku petani terhadap keberhasilan program Upsus. Hasil evaluasi koefisien struktural secara rinci dapat dilihat pada Tabel 7. berikut ini.

Tabel 7. Evaluasi Koefisien Jalur Struktural

\begin{tabular}{lccc}
\hline Konstruk & $\begin{array}{c}\text { Original } \\
\text { Sample }\end{array}$ & T-statistic & $\boldsymbol{P}$-Value \\
\hline KP -> KPU & 1,307 & 7,689 & 0,000 \\
KP -> PP & 1,035 & 16,817 & 0,000 \\
PP -> KPU & $-0,309$ & 2,108 & 0,036 \\
SI -> KPU & $-0,054$ & 0,564 & 0,573 \\
SI -> PP & $-0,067$ & 0,972 & 0,331 \\
\hline
\end{tabular}

Sumber: Data primer (diolah), 2018. 
Hasil evaluasi struktural pada Tabel 7. menunjukkan bahwa persamaan model struktural yang terbentuk antara konstruk eksogen dan konstruk endogen adalah sebagai berikut.

$\mathrm{PP} \quad=1,035 \mathrm{KP}-0,067 \mathrm{SI}$

KPU $=1,307 \mathrm{KP}-0,054 \mathrm{SI}-0,309 \mathrm{PP}$

Hasil analisis model struktural yang menjelaskan besarnya pengaruh yang meliputi: (1) pengaruh kompetensi penyuluh dan sifat inovasi terhadap perilaku petani; (2) kompetensi penyuluh dan sifat inovasi terhadap keberhasilan program Upsus; dan (3) perilaku petani terhadap keberhasilan program Upsus dapat dilihat pada Gambar 1. berikut ini.

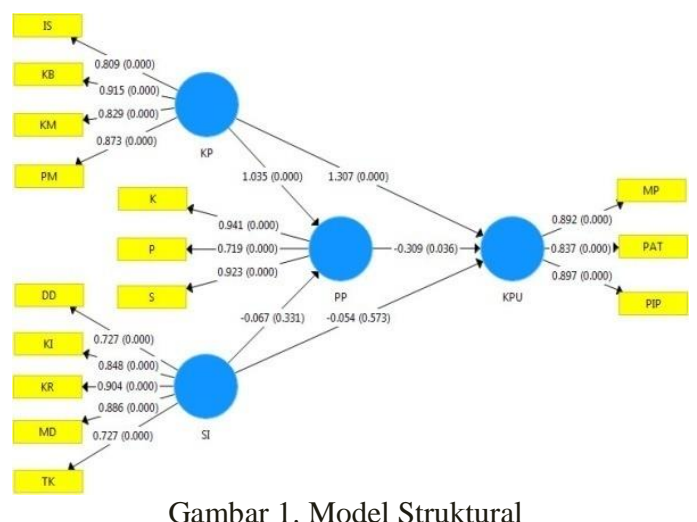

Hasil evaluasi jalur struktural pada Tabel 7. dan model struktural pada Gambar 1. merupakan hasil pengujian hipotesis dari masing-masing jalur yang terbentuk dalam model untuk mengetahui pengaruh variabel eksogen terhadap variabel endogen. Secara rinci pengaruh variabel eksogen terhadap variabel endogen dapat dijelaskan sebagai berikut.

1. Pengaruh kompetensi penyuluh dan sifat inovasi terhadap perilaku petani

Konstruk kompetensi penyuluh (KP) berpengaruh nyata pada taraf signifikansi $5 \%(\alpha=0,05)$ terhadap konstruk perilaku petani (PP) dengan nilai $p$-value sebesar 0,000 dan t-hitung sebesar 16,817 >1,986 (ttabel). Kompetensi penyuluh yang berpengaruh nyata terhadap perilaku petani padi di Kabupaten Tabanan karena proses penyuluhan berpedoman kepada petunjuk teknis dan pelaksanaan program Upsus. Hasil penelitian Maryani (2014) menunjukkan bahwa kompetensi penyuluh mempengaruhi perilaku petani dalam adopsi inovasi Pengelolaan Tanaman Terpadu (PTT) pada Sekolah Lapang Pengelolaan Tanaman Terpadu (SLPTT) di Kecamatan Sukawati, Kabupaten Gianyar. Hal ini menunjukkan bahwa penyuluh di Kabupaten Tabanan memiliki peranan penting dalam meningkatkan pengetahuan, sikap, dan keterampilan petani sehingga penerapan inovasi program Upsus menjadi optimal.

Konstruk sifat inovasi (SI) berpengaruh tidak nyata pada taraf signifikansi $5 \%(\alpha=0,05)$ terhadap konstruk perilaku petani (PP) dengan nilai p-value sebesar 0,331 dan t-hitung sebesar 0,972 <1,986 (t- tabel). Maryani (2014) mengungkapkan bahwa kegiatan usahatani yang dilakukan oleh petani biasanya turun temurun, cara bercocok tanam yang dilakukan biasanya mengikuti kebiasaan yang dilakukan oleh keluarganya. Soekartawi (2006) mengungkapkan bahwa pengalaman seseorang dalam berusahatani berpengaruh dalam menerima inovasi dari luar. Zaltman, dkk (1973) mengungkapkan bahwa warga masyarakat dapat cepat menerima inovasi apabila dirasakan itu hal yang baru bagi mereka. Sifat inovasi program Upsus berpengaruh tidak nyata terhadap perilaku petani padi di Kabupaten Tabanan karena inovasi yang ditawarkan program Upsus berupa bibit padi inbrida varietas situbagendit, tuwoti, cigeulis, inpari 30, ciherang, dan cibogo cenderung tidak terlalu memiliki perbedaan cara budidaya dengan jenis bibit varietas lainnya. Hal ini menunjukkan bahwa petani padi di Kabupaten Tabanan cenderung menilai inovasi program Upsus merupakan suatu inovasi yang tidak terbarukan sehingga sifat inovasi tersebut berpengaruh tidak nyata terhadap perilaku petani. Hal ini menunjukkan bahwa perubahan perilaku petani tidak selalu dikarenakan adanya inovasi, melainkan juga karena adanya peranan seorang penyuluh dalam memberikan penyuluhan kepada petani.

2. Pengaruh kompetensi penyuluh dan sifat inovasi terhadap keberhasilan program Upsus

Konstruk kompetensi penyuluh (KP) berpengaruh nyata pada taraf signifikansi $5 \%(\alpha=0,05)$ terhadap konstruk keberhasilan program Upsus (KPU) dengan nilai $p$-value sebesar 0,000 dan t-hitung sebesar 7,689 $>$ 1,986 (t-tabel). Roger (2003) mengungkapkan bahwa faktor-faktor yang mempengaruhi kecepatan petani dalam pengadopsian suatu inovasi salah satunya karena gencarnya usaha agen pembaharu atau penyuluh dalam mempromosikan inovasi. Penyuluh di Kabupaten Tabanan yang berkompeten mampu meningkatkan pengetahuan, sikap, dan keterampilan sehingga program Upsus dapat berjalan sesuai petunjuk teknis dan pelaksanaan. Petani yang berperan sebagai pelaku usahatani memiliki peranan yang penting dalam menunjang keberhasilan usahataninya. Hal ini menunjukkan bahwa kompetensi penyuluh di Kabupaten Tabanan memiliki peranan penting untuk mempromosikan inovasi sehingga petani yang bergerak sebagai pelaku usahatani mampu menerapkan inovasi yang ditawarkan dalam program Upsus.

Konstruk sifat inovasi (SI) berpengaruh tidak nyata pada taraf signifikansi $5 \%(\alpha=0,05)$ terhadap konstruk keberhasilan program Upsus (KPU) dengan nilai $p$-value sebesar 0,573 dan t-hitung sebesar 0,564 $<$ 1,986 (t-tabel). Firdaus (2010) mengungkapkan bahwa produktivitas yang tinggi hanya dapat dicapai dengan menggunakan cara budidaya dan teknologi tepat guna. Roger (2003) mengungkapkan bahwa faktor-faktor yang mempengaruhi kecepatan petani dalam pengadopsian suatu inovasi salah satunya karena gencarnya usaha agen pembaharu atau penyuluh dalam mempromosikan inovasi. Sifat 
inovasi berpengaruh tidak nyata terhadap keberhasilan program Upsus karena bantuan yang diberikan pada saat pelaksanaan program Upsus hanya bibit padi inbrida varietas situbagendit, tuwoti, cigeulis, inpari 30, ciherang, dan cibogo. Hal ini tentu tidak sebanding dengan capaian target dari program Upsus yaitu meningkatnya produktivitas, perluasan areal tanam, dan peningkatan indeks pertanaman. Bantuan dari sebelum pelaksanaan program upsus dimanfaatkan untuk menunjang pelaksanaan program Upsus seperti bantuan alat dan mesin pertanian traktor, mesin penyosohan gabah, dan alat semprot. Petani juga masih menghadapi beberapa kendala seperti jaminan ketersediaan air sehingga petani perlu meminjam air kepada petani lainnya pada saat ketersediaan air tidak mencukupi. Walaupun sifat inovasi berpengaruh tidak nyata terhadap keberhasilan program Upsus, berkat adanya sinergritas antara bantuan program Upsus dengan bantuan program sebelumnya membantu petani melaksanakan program Upsus sesuai petunjuk teknis dan pelaksanaan. Hal ini menunjukkan bahwa keberhasilan program Upsus di Kabupaten Tabanan bukan tergantung kepada inovasi yang ditawarkan, melainkan kepada kompetensi seorang penyuluh untuk mempromosikan inovasi dan adanya sinergritas dari berbagai bantuan program pemerintah sehingga petani sebagai pelaksana mampu menjalankan program Upsus secara lebih optimal sesuai petunjuk teknis dan pelaksanaan program.

3. Pengaruh perilaku petani terhadap keberhasilan program Upsus di Kabupaten Tabanan

Konstruk perilaku petani berpengaruh nyata pada taraf signifikansi $5 \%(\alpha=0,05)$ terhadap konstruk keberhasilan program Upsus dengan nilai $p$-value sebesar 0,036 dan t-hitung sebesar 2,108 > 1,986 (ttabel). Hal ini menunjukkan bahwa perilaku petani berpengaruh nyata terhadap keberhasilan program. Adanya peran dari penyuluh sebagai pendamping, aparat keamanan/militer sebagai pengawas pelaksana, dan kalangan akademisi sebagai konsultan menjadikan petani padi di Kabupaten Tabanan melaksanakan program Upsus sesuai dengan petunjuk teknis dan pelaksanaan. Hasil penelitian ini sejalan dengan hasil penelitian Maryani (2014) yang mengungkapkan bahwa perilaku petani berpengaruh positif terhadap adopsi inovasi sekolah lapang pengelolaan tanaman terpadu di Kecamatan Sukawati, Kabupaten Gianyar. Hal ini menunjukkan bahwa perilaku petani menjadi salah satu penentu keberhasilan program Upsus di Kabupaten Tabanan karena petani berperan sebagai pelaksana program.

\section{SIMPULAN DAN SARAN}

\section{Simpulan}

Kesimpulan hasil penelitian ini adalah

1. Kompetensi penyuluh di Kabupaten Tabanan yang meliputi keterampilan berkomunikasi, penguasaan materi, kemampuan memotivasi, dan interaksi sosial berpengaruh nyata terhadap perilaku petani padi. Sifat inovasi yang terdiri atas keuntungan relatif, kesesuaian inovasi, tingkat kerumitan, dapat dicoba, dan mudah diamati berpengaruh tidak nyata terhadap perilaku petani.

2. Kompetensi penyuluh di Kabupaten Tabanan yang terdiri atas keterampilan berkomunikasi, penguasaan materi, kemampuan memotivasi, dan interaksi sosial berpengaruh nyata terhadap keberhasilan program Upsus. Sifat inovasi yang meliputi keuntungan relatif, kesesuaian inovasi, tingkat kerumitan, dapat dicoba, dan mudah diamati berpengaruh tidak nyata terhadap keberhasilan program Upsus.

3. Perilaku petani padi yang berkaitan dengan pengetahuan, sikap, dan keterampilan berpengaruh nyata terhadap keberhasilan pelaksanaan program Upsus di Kabupaten Tabanan.

\section{Saran}

Saran dalam penelitian ini adalah

1. Kompetensi penyuluh di Kabupaten Tabanan dalam menguasai materi untuk mengidentifikasi masalah-masalah baru perlu ditingkatkan melalui program pendidikan dan pelatihan kepada penyuluh pertanian agar petani padi yang berpartisipasi dalam program Upsus lebih cepat menemukan solusi untuk bertindak.

2. Pengkajian terhadap kesesuaian spesifikasi mesin traktor pada program Upsus perlu ditingkatkan agar inovasi yang ditawarkan sesuai dengan kondisi lahan, dan kebutuhan petani padi di Kabupaten Tabanan.

3. Pendidikan non formal melalui pelatihan maupun bimbingan teknis kepada petani perlu ditingkatkan agar petani padi di Kabupaten Tabanan yang mayoritas mengikuti jenjang pendidikan formal hingga sekolah dasar mampu mengelola usahataninya dengan lebih baik.

4. Dukungan pemerintah terhadap infrastruktur irigasi melalui rehabilitasi jaringan irigasi tersier maupun pembuatan dam parit perlu ditingkatkan lagi agar menjamin ketersediaan air dan mampu mengalir dari sawah di bagian hulu hingga hilir pada saat musim kemarau untuk mengoptimalkan perluasan areal tanam, dan peningkatan indeks pertanaman padi.

5. Pengembangan penelitian lain perlu dilakukan dengan tambahan konstruk karakteristik petani dan kajian bidang ekonomi dalam program Upsus agar adopsi inovasi program Upsus dilakukan secara berkelanjutan.

\section{UCAPAN TERIMAKASIH}

Penulis mengucapkan terimakasih kepada seluruh petani di Kabupaten Tabanan, seluruh dosen di fakultas pertanian Universitas Udayana, seluruh pegawai di lingkungan Dinas Pertanian Kabupaten Tabanan, dan pihak-pihak lainnya yang senantiasa membantu dalam penyusunan E-jurnal ini. 


\section{DAFTAR PUSTAKA}

Dinas Pertanian. 2017. Surat Keputusan Nomor 029/DISTAN/2017 Tentang Penetapan Kelompoktani Penerima Bantuan Pemerintah Kegiatan Pengelolaan Produksi Tanaman Serealia Berupa Budidaya Padi Inhibrida Tahun Anggaran 2017. Tabanan: Dinas Pertanian.

BPS. 2016. Produksi, Luas Panen, dan Produktivitas Padi di Indonesia Tahun 2013-2016. Kementrian Pertanian. Indonesia. (edisi online), [diakses tanggal 11 September 2017]. Tersedia: http://www.pertanian. go.id/Data5tahun/ATAP-TP2016/00-PadiN asional.pdf.

BPS. 2016. Berita Resmi Statistik Produksi Padi, Jagung, dan Kedelai Tahun 2015. Badan Pusat Statistik. Provinsi Bali. (edisi online), [diakses tanggal 11 September 2017]. Tersedia: https://bali.bps.go.id/webbeta/we bsite/brs_ind/brsInd-20 160701145314.pdf.

Firdaus, M. 2010. Manajemen Agribisnis. Jakarta: PT Bumi Aksara.

Ghozali, I. 2011. Structural Equation Modeling Metode Alternatif Dengan Partial Least Square. Semarang: Badan Penerbit Universitas Diponegoro.

Hernanto, F. 1996. Ilmu Usahatani. Jakarta: Penebar Swadaya.

Kast, F.E dan Rosenzweig, J.E. 1995. Organisasi dan Manajemen Jilid 1. Jakarta: PT Bumi Aksara.

Kementan. 2015. Peraturan Menteri Pertanian Nomor 03/Permentan/0T.140/2/ 2015 Tentang Pedoman Upaya Khusus (Upsus) Peningkatan Produksi Padi, Jagung, dan Kedelai Melalui Program Perbaikan Jaringan Irigasi dan Sarana Pendukungnya Tahun Anggaran 2015. Kementrian Pertanian. Indonesia. (edisi online), [diakses tanggal 12 Januari 2018]. Tersedia: https://diperpautkan.bantulkab.go .id/filestorage/dokumen/2017/03/Permenta n\%20Nomor\%2003-2015\%20Pedoman\%2 0Upsus\%20pajale.pdf.

Kementan. 2017. Pedoman Pelaksanaan Kegiatan Padi Tahun 2017. Direktorat Jenderal Tanaman Pangan Kementrian Pertanian.
Indonesia. (edisi online), [diakses tanggal 15 September 2017]. Tersedia: http:// tanamanpangan.pertanian.go.id/assets/front /uploads/document/PEDOMAN\%20PELA KSANAAN\%20KEGIATAN\%20PADI\%2 02017\%20(TTD\%20DIRJEN).pdf.

Marius, J.A. 2007. "Pengembangan Kompetensi Penyuluh Pertanian di Provinsi Nusa Tenggara Timur" (disertasi). Bogor: Institut Pertanian Bogor. (edisi online), [diakses tanggal 13 September 2017]. Tersedia: http://repository.ipb.ac.id/jspui/b itstream/123456789/40752/9/2007jam.pdf.

Maryani, N. D. 2014. “Adopsi Inovasi PPT pada sekolah lapang pengelolaan tanaman terpadu (SL-PTT) Padi di Kecamatan Sukawati, Kabupaten Gianyar" (tesis). Denpasar: Universitas Udayana.

Nursalam dan Efenfi, F. 2008. Pendidikan Dalam Keperawatan. Jakarta: Salemba Medika.

Rogers, E.M. 2003. Diffusion of Innovation Fifth Edition. New York: Free Press.

Soekartawi. 1988. Prinsip Dasar Komunikasi Pertanian. Jakarta: UI-Press.

Soekartawi. 2006. Analisis Usahatani. Jakarta: UIPress.

Sugiyono. 2010. Metode Penelitian Pendidikan Pendekatan Kuantitatif, Kualitatif, dan $R \& D$. Bandung: Alfabeta.

Wijaya, I G.M.A.S. 2016. "Efektivitas Alokasi Input Usahatani Padi Dalam Program Upsus Pajale di Subak Gadungan Delod Desa, Desa Gadungan, Kabupaten Tabanan" (Skripsi). Denpasar: Universitas Udayana.

Zaltman, C., Duncan, R., and Holbek, J. 1973. Innovations and Organisations. New York: Wiley. 